\title{
Race and Objectivity in the Writing of J. P. Rushton and His Critics
}

\author{
Frances Ranger \\ University of Waterloo
}

J.-Philippe Rushton considère que l'espèce humaine se divise en trois races: la mongoloüde, la caucasoïde et la négroïde. Il prétend en outre qu'il existe une hiérarchie des races (mongolö̈de $>$ caucasoüde $>$ négroïde) que l'on peut établir selon plusieurs caractéristiques, dont l'intelligence. Les critiques de Rushton remettent en question sa hiérarchie des races et son objectivité. Cependant, la plupart d'entre eux ne mettent pas en cause l'existence de plusieurs races humaines. Pourtant, ni Rushton ni ses critiques n'ont pu fournir une définition scientifique acceptable de ce qui constituerait une " race». Or, cette définition serait indispensable pour la poursuite de recherches significatives dans le domaine. Selon Campbell (1975 : 399), l'objectivité exige l'élimination de jugements vis-à-vis de l'objet d'étude. L'objectivité ainsi définie serait impossible et non souhaitable dans le domaine de la recherche sur les races.

J. Philippe Rushton, a psychologist and Guggenheim Fellow at the University of Western Ontario, does not shy away from controversy. His theories on racial differences between human groups have elicited dozens of critical articles in both the scientific and popular media, incited student protests, and even prompted an investigation by the Ontario Provincial Police. ${ }^{1}$ Rushton argues that three races constitute the human species - Negroid (black), Caucasoid (white), and Mongoloid (Asian; Rushton also uses "Oriental") - that can be ranked hierarchically on a number of traits, including intelligence and reproductive strategies. Mongoloids and Negroids always occupy opposite poles on these scales, and Caucasoids fall somewhere in the middle. Rushton writes prolifically on these claims, and virtually every published article receives a response in print, either simultaneously or as a follow-up piece. Rushton resolutely attempts to maintain the appearance of scientific values, particularly disinterestedness and organized skepticism, ${ }^{2}$ in his writing, claiming that "known facts" 
exist "that require explanation" (1991b, p. 500). Other psychologists have objected to this practice, saying that Rushton "hides behind a cloak of objectivity" (Fairchild, 1991, p. 109), and some have even gone so far as to call him a "charlatan" (Cernovsky, 1995, p. 32). Posterity and continuing research will evaluate the merits of Rushton's theories; however, an understanding of how the term "race," the concept at the root of the debate, is only loosely defined, and how both Rushton and his critics claim the ideal of "objectivity," using the term to strengthen their own arguments while devaluing their opponents' arguments, will provide insight into the nature of the debate. Fundamentally, the idea of race and the ideal of objectivity would seem to be incompatible concepts; ethically, at least, because of the problems that could result from irresponsible application of this research, it seems undesirable to link the two concepts.

Campbell (1975) says to be objective "is to treat something as an object, as external, as impersonal," and thereby devalue it (p. 398), later adding that "one must accept the responsibility for doing away with values in relation to the reality studied" (p.399). These observations are clearly relevant to Rushton's work, particularly since he deals with the relative ranking - and it would appear, relative worth - of human beings. Abraham Maslow (quoted by Campbell, p. 404) calls objectivity the process of "looking at something that is not you, not human, not personal, something independent of you the perceiver.... You the observer, are, then, really alien to it, uncomprehending and without sympathy or identification...." Thus, to revere objectivity, at least with respect to research concerning humans, is to devalue humanity. Objective appraisals of human beings have in the past served as warrants for various eugenics movements, ${ }^{3}$ including the most extreme eugenics program ever undertaken, the Holocaust.

Rushton's theories stipulate three main races, which he claims evolved separately from a common human ancestor and, in responding to different evolutionary pressures, adapted different characteristics and strategies to better meet the demands of their environment. As he explains:

[T] he currently accepted view of human origins, the "African Eve" theory, posits a beginning in Africa some 200,000 years ago, an exodus through the Middle East with an African/non-African split about 110,000 years ago, and a Caucasoid/Mongoloid split about 40,000 years ago. Evolutionary selection pressures are different in the hot savannah where Africans evolved than in the cold arctic where Mongoloids evolved. The farther north the populations migrated, out of Africa, the more they encountered the cognitively demanding problems of gathering and storing food, gaining shelter, making clothes, and 
raising children successfully during icy winters. As the original African populations evolved into Caucasoids and Mongoloids, they did so in the direction of larger brains, slower rates of maturation, and lower levels of sex hormone with concomitant reductions in sexual potency, aggressiveness, and impulsivity, and increases in family stability, forward-planning, self-control, rule-following, and longevity (1995a, p. 374).

Rushton cites no sources for this information, assuming (or maybe just hoping) that his audience will simply accede upon reading "currently accepted." He deploys the "African Eve" theory as a type of testimony, immediately follows his summary of it with his own ideas about the implications for such an evolutionary split (i.e., larger brains, slower maturation, etc., for Mongoloids and Caucasoids than for Negroids). He makes no effort to delimit where the commonly held belief ends and his own beliefs begin.

In the following paragraph, Rushton pursues this strategy further, saying that "[e]volutionary selection explains the how and why of the worldwide racial clustering," (p. 374), again neatly packaging his own theories into the realm of commonly accepted views, closing them off from debate. Notably, he does not define the term "race" or clarify the standards he uses to classify people, beyond this appeal to "obvious differences":

Mongoloids, Caucasoids, and Negroids can be distinguished on the basis of obvious differences in skeletal morphology, hair and facial features, and molecular genetic information (p. 378).

Rushton elsewhere suggests that his divisions accord with "common usage" (cited in Weizmann, Wiener, Wiesenthal, and Ziegler, 1996, p. 8).

To the extent that Rushton accounts for the notion of race, it is by essentially begging the question; he states that people are of a particular race because of where their ancestors were born (and where their ancestors were born is identified by their race).

A "Negroid" is someone whose ancestors were born in sub-Saharan Africa, and mutatis mutandis for "Caucasoid" and "Mongoloid." This definition requires temporal bounds, to be set by the best theory of human dispersal. Thus, if Homo sapiens first appeared in Africa, branched off into Europe about 110,000 years ago, and into Asia 70,000 years after that, a "Negroid" is someone whose ancestors between 4000 and (to accommodate recent migrations) 20 generations ago were born in sub-Saharan Africa - mutatis mutandis, again, for Caucasoid and Mongoloid (1995a, p. 378). 
The device of "mutatis mutandis," that is "with the necessary changes," allows him to paper over controversy - to avoid specifying where, precisely, Caucasoids and Mongoloids evolved, questions that are much more hotly disputed than the general belief that the human race originated in Africa. In essence, the separation of people into races in Rushton's theories relies on conventional divisions on the basis of appearance. Thus, what seem to be statements of truth are more accurately described as assertions of belief, and it is upon these assertions that Rushton builds his theories.

Allen and Adams (1992, p. 164) highlight the difficulties with this loose and ad hoc approach, noting that Rushton uses the terms "black" and "Negroid" interchangeably in a 1988 article, even though some groups that he regards as non-Negroid are darker on average than some groups he regards as Negroid. They make an additional point about Rushton's inability to account for within-race differences, along with a thinly veiled insinuation about his character:

In fact, the African "race" displays so much within "race" variability on so many dimensions even those struck nearly blind by racism should be able to detect it with the naked eye: witness the Pygmy and the Watusi (1992, p. 165).

Some critics even more overtly accuse Rushton of character flaws (cf. Cernovsky, 1992, 1995, 1996; Luther, 1995; Weizmann et al., 1996).

Rushton's theories of racial differences are, by their very nature, dependent on the a priori acceptance of the existence of races, and, in fact, many of his critics do not question this assumption. Several use the language of "race" uncritically, granting Rushton the foundation of his argument and focusing instead on critiquing his interpretations of data (cf. Cain \& Vanderwolf, 1990; Cernovsky, 1996; Gorey \& Cryns, 1995; Miller, 1993, and others). Fairchild (1991), however, offers a rare sociopolitical view on the concept of race:

(a) [Race] is an ideological invention that supported European and American imperialism; (b) the definition of race as a reproductively isolated group one that has unique phenotypic characteristics - results in thousands of races, not three; (c) within each of [Rushton's] three "racial" groups, the variation in attributes and characteristics exceeds the average between-group differences; and (d) "racial" classification ignores the overwhelming commonality in the genetic histories of Homo sapiens, and this biological evidence points to one race, not three or thousands (p. 103).

Fairchild makes clear the difficulties inherent in trying to justify the notion of human races to begin with, let alone the very dicey nature of any theories built on those constructs; he then goes on to concede that "various 'racial' groups differ on a wide 
variety of physical and psychological measures cannot be denied," but he attributes between-group differences to "nurture" rather than "nature" (pp. 103-5). Yee (1995, p. 388) calls race a "pseudoscientific myth," and Allen and Adams (1992) suggest the term "ethnic groups" as more appropriate to deal with between-group differences until "race" is adequately defined. Of course, such a usage would foreground cultural and environmental distinctions between peoples, rather than genetic differences, so it is safe to assume that Rushton and other race researchers will continue to ignore their suggestion.

Rushton's theory depends not only on the supposition that races exist and that they evolved at different times, but that their evolution took place under different pressures of selection. Beginning with data that he interprets to indicate a difference in average intelligence between the races (Mongoloids > Caucasoids > Negroids), he specifies that larger brains and higher intellectual abilities evolved to meet the rigours of the more "cognitively demanding" Arctic, where planning became necessary for survival (1995a, p. 374). He states "[u]nless large brains substantially contribute to fitness, therefore they would not have evolved [sic]" (Rushton, 1990, p. 792), a clearly teleological and circular argument (Fairchild, 1991, p. 103). He relies on his audience's implicit acceptance of his theory without explaining in detail how a colder environment would happen to select for those characteristics that our society deems most desirable. However, Miller, who "accepts his description of the facts," questions his interpretation of them, saying, "the biological selection mechanisms in the area in which Negroids emerged would not have selected for the characteristics Rushton reports" (1993, p. 665). Why, for instance, would higher sex drives and increased aggression - two Negroid characteristics in Rushton's chain of being - be advantageous in Africa? The very building blocks of Rushton's theory are much less certain than he would have it appear.

Of course, any scientist with a career at stake will want his or her flagship theories to appear sound and reasonable and relatively free of doubt, and publication of these theories is primarily an exercise in persuasion on these points. In scientific reports, researchers lean heavily toward expletive phrasing and the passive voice, such as "it would appear that" or "it is understood that" (Halloran, 1997, p. 43; Riley, 1991). These devices remove human agency from the sentence, giving the impression of greater objectivity. Rushton exemplifies the strategy: "it seems reasonable to conjecture," "suggested," and "are envisaged as" refer to his own work (1991b).

This technique also allows him to "slip in" as fact the rather shaky foundations of many claims. Recall how he ties his whole notion of differential racial evolution to the relatively well-established "African Eve" theory. The differential evolution part of his theory, its very core, is stated as fact. He "permits" his readers to question a 
more tentatively stated postulation, "[m]ultifarious sources of evidence suggest that the racial differences in intelligence are partly genetic" (1995a, p. 375; italics added; see Hyland, 1996, on hedging in scientific discourse). Other presumptions inherent in that statement - that there are multiple human races, and those races demonstrate differences in intelligence - are not up for debate.

These moves are standard deployments of what Gilbert and Mulkay term the "empiricist repertoire," a bag of linguistic procedures that reify assertions, that solidify, stabilize, and factualize claims; in a word, it is objectification. Rushton reifies his own arguments, and he ironizes the arguments of his opponents, a strategy of subjectification, focusing on their cases as "talk or writing ... which is motivated, distorted or erroneous in some way" (Potter, 1996, 107). Rushton uses the phrases "incorrectly claims" and "seems to allege," for instance, to describe the work of Cernovsky, a psychologist who opposes his theories (1991b, pp. 500-1; italics added). Both verbs connote a human agent who seems to have a non-scientific, non-objective agenda. In response to a negative article by Zuckerman, Rushton (1991a) says of the author that he "tactically maneuvered around the main thrust of $r-K$ theory," "failed to mention ... data," and "exploit[ed] victims of World War II for current political purpose" (pp. 983-4).

In comparison to many of his critics, however, Rushton is rather reserved in his use of harsh criticism and the attribution of motives. Zuckerman, in the article that prompted Rushton's response had implied "misrepresentation" and "racist ideology" in Rushton's work (1990). In an article published simultaneously with Rushton's response to his work, Zuckerman (1991, p. 984) states:

As in previous responses to critiques of his work, Rushton restates his "truth," ignoring or sidestepping the major criticisms and adding new "data" to clinch his case ... His unshakable belief in the absolute truth of his conclusion suggests an attitude that is immune to scientific criticism.

Zuckerman's criticisms border on the ad hominem. He reproaches Rushton for failing to engage in scientific debate and for failing to consider alternative explanations. His use of quotation marks for "truth" and "data" makes apparent his belief that these terms are inappropriately used. Other of Rushton's critics are even less restrained and directly attack Rushton's worth as a researcher and, implicitly, as a human being. Cain and Vanderwolf, for instance, stop just short of calling him a fraud:

Zuckerman and Brody (1988) concluded from a partial analysis of Rushton's theory and his cited evidence that he (1) used strained logic, (2) used sources that lack credibility, (3) selectively cited data that support his theory, (4) used 
sources that did not control for socio-economic class, and (5) did not use statistical analysis to establish his claims.... In addition, we found that Rushton miscited conclusions and numerical data from certain studies, without providing an explanation for the divergence from the original published form of the conclusions and data (1990, p. 783).

Cernovsky, a colleague of Rushton's in the University of Western Ontario's psychology department, does not stop short. He has repeatedly referred to Rushton as a "charlatan" $(1995,1996)$. Cernovsky makes his point quite emphatically, assembling "objective" and "scientific" criteria to do so:

If we define charlatanism as a combination of inappropriate methods (e.g., tape measures of head perimeter presented as measures of intelligence), blatant misunderstanding of basic contemporary statistics (e.g., presentation of correlation coefficients below .30 from non-representative samples as definite indices of causal relationships), and of grandiose claims based on blatantly convenient selection of supportive data and supportive references only, Rushton meets all these criteria (1996, p. 32).

Among the metrics on which Cernovsky seeks to discredit Rushton are the Mertonian norms of "universalism" (that knowledge claims are tested by "pre-established, impersonal criteria that render them consonant with observation and previously established knowledge"), "organized skepticism" (that scientists temporarily suspend judgment in order to scrutinize beliefs critically against empirical and logical criteria of argument), and "humility" (Prelli, 1997, pp. 87-8).4 As Prelli (1997) suggests implicitly, and Taylor (1998, p. 58-63) makes explicit, the Mertonian norms are frequently rhetorical moves of demarcation, each side using them to draw a line dividing their own "scientific" work and their opponents' "unscientific" work. Cernovsky uses these conventional standards of scientific rhetoric to refute Rushton - and to demonstrate that Rushton is "unscientific" - without making explicit, in this case, his belief that Rushton's work is immoral and irresponsible. Elsewhere he states that "[Rushton's speculations] cause major psychological harm to millions of black children and adults (with respect to self-esteem, career expectations, interracial relationships, etc.)" (Cernovsky, 1992, p. 64), suggesting that a psychologist should consider the effects of his or her research before publishing it and lessening the demand for impersonal "objectivity." However, the sentence that follows it serves up a contradiction:

Since Rushton publicly presents himself as a psychologist, the onus is on bona fide scientists in this field to restore the reputation of psychology as an objective science (p.64). 
Here he privileges the need for psychology to be "objective." He demands that Rushton be both "objective" and empathetic, impersonal yet socially responsible: qualities that would seem to be at odds.

Rushton, for his part, strongly agrees with the need for psychology to be objective. He is clearly a scientific realist who believes that facts exist in the world that scientists can collect and interpret as data (Gross, 1991). He claims that scientists have a duty to explain these pre-existent facts:

A truth must be faced: Across time, country, and circumstance, Africandescended peoples show similarities that, on average, differentiate them from Caucasoids, who, in turn, show characteristics differentiating them from Orientals. It may be worth recalling the words of the deeply pious Blaise Pascal when faced with the Copernican hypothesis: "If the earth moves, a decree from Rome cannot stop it." Readers may fervently wish that genetically based differences in behaviour did not exist, but the data show otherwise (1991a, p. 984).

One critic concludes that Rushton compares himself with Copernicus here (Zuckerman, 1991) but rather, he compares himself with Pascal and his data to Copernican theory. The analogy is fairly complex: (1) Pascal did not collect the data or invent the hypothesis; he is faced with it. Rushton is faced with data that he did not gather himself. ${ }^{(2)}$ The Church of Rome in the seventeenth century was a dogmatic institution that was resistant to change. It regarded a challenge to the Ptolemaic cosmos as a challenge to its very authority and forbade the teaching of Copernican theory. Rushton implies that psychology is also dogmatic and disinclined to change. Rushton recounts numerous times that his articles have been subjected to "unusual treatment" (1994, p. 264), and, indeed, he was barred from teaching in person at the University of Western Ontario for a short period of time. ${ }^{6}$ (3) After much resistance, Copernicus' heliocentric cosmos became accepted as fact. Rushton suggests that his racial theories will survive this period of doubt to become longstanding and accepted fact as well. Recall that Zuckerman, for one, sees the dogma on the other foot, characterizing Rushton's attitude as an "unshakable belief" immune to criticism (1991, p. 984).

Rushton's critics also strongly imply that, if he is not racist himself, at least he should be more sensitive to the racist implications of his claims, and the racist ends to which his work can be put. Cernovsky is perhaps the least equivocal on this front, charging that Rushton's blacks are "oversexualized and dull creatures prone to crime and mental disease, and genetically inferior to Caucasians" (1996, p. 32). Rushton 
denies bias, and rejects the notion that researchers should consider the potential social implications of their work before making it public. He, in particular, does not accept responsibility for any subsequent political or social events that can be traced back to the research.

Rushton asserts that the data and his interpretations thereof reflect truths about the world that he cannot deny; and sees only an abstract, scientific fidelityto-the-data sort of morality as relevant. "[I]t is immoral to know," he says, "or even suspect, the truth [about racial differences] and to remain silent" (1994, p. 277). It would seem that the possible social and political implications for his work are far less important to him - indeed, virtually irrelevant - compared to the value of scientific inquiry. He cites four principles for inquiry and debate that he suggests will "improve the current chilly climate for research on race differences":

1. Seek the truth and speak it as you know it, directly and not in code.

2. Do not speculate about motives unless you have very good grounds for doing so. Integrity is the only character trait that is of concern when evaluating ideas and their impact.

3. Do not apologize or act embarrassed about racially sensitive research or its results. To do so lends credence to the belief that you think you are doing something wrong.

4. Zealously protect freedom of scientific inquiry (1994, p. 277).

That racists and extremists could co-opt his work to their purposes is not, he avers, important to his devotion to scientific truth. Indeed, to promote his work, Rushton has appeared at speaking engagements with people such as Jared Taylor, who claims that "racial diversity is a terrible weakness, not a strength" in the United States and that "we must reject the suicidal fad of multi-racialism and return to the wisdom of our forebears" ("1996 Conference").? His willingness to speak on the same platform as Taylor might imply something about his personal beliefs, although he carefully eschews terms such as "inferior" and "superior" to refer to races (Rushton, 1994, p. 270).

Of all Rushton's critics I have examined, only Fairchild (1991) explicitly states that total objectivity is, ultimately, an impossible and undesirable ideal for social science inquiry. He notes: 
Research does not accumulate in a vacuum. It is a product of organized society and is conducted according to socially defined rules, values, and conventions ... As such, social science research is shaped by, and shapes, public opinion about a wide variety of issues.... (p. 108)

Public opinion, in turn, influences public policy, which is why Fairchild goes on to state that " $[a] n$ extra degree of caution should be exercised in studies that could reinforce racist ideology" (1991, p. 109). "Data," though it may correlate with some realworld phenomena, is the product of human intervention and interpretation. What researchers deem relevant to study and the way they interpret the products of study change as the outcome of a changing society. Researchers, then, should not try to camouflage the process and beliefs that contribute to their work. Unlike other critics, Fairchild does not attribute the quality of "objectivity" even to his own work:

If ideology is inextricably tied to the generation of knowledge, then all social science writings - including this one - involve certain ideological biases or political agendas. These biases are typically unstated. The author's ideological biases are as follows: (a) The idea of inherited "racial" differences is false; instead, "race" is a proxy for a host of longstanding historical and environmental variables. (b) Social science has the mandate of applying its theories and methods to alleviate human suffering and inequality. (1991, p. 112)

Because social science has the power, the "mandate," to improve the situation for humanity to aim merely for "objectivity" - the depersonalization and devaluation of the human subject - is to strive for a lesser goal.

Rushton and his critics should not aim for and affect to attain the quality of "objectivity" in their work. This quality, in so far as it necessitates the depersonalization and dehumanization of the subject of study, is not appropriate for race research, with its profound implications for the influence of public opinion and social policy and their ability, in turn, to affect directly the quality of life for millions of people. In addition, for any study of race to be meaningful, the term "race" must first be clearly defined. A first step in the scientific process is the definition of the object of study. Thus far, the work of Rushton and of his critics has failed to establish a reliable, comprehensive, and ultimately workable definition for "race." Until they do so, all race research, apart from questions of objectivity and motive, lacks scientific value and substance. 


\section{Notes}

1 After presenting a paper on his racial theories to the American Association for the Advancement of Science in January 1989, Rushton was enveloped by media controversy in Canada. During the ensuing months, the Attorney Generai of Ontario ordered a police investigation of Rushton to determine whether he had violated the Criminal Code of Canada, chapter C46, 319, paragraph 2: "Everyone who, by communicating statements, other than private conversation, wilfully promotes hatred against any identifiable group is guilty of (a) an indictable offence and is liable to imprisonment for a term not exceeding two years." The investigators eventually concluded that Rushton had not committed a federal offence and, at a press conference announcing the decision, the Attorney General called Rushton's theories "loony but not criminal" (events discussed in Pearson, pp. 216, 236-7).

2 Robert K. Merton worked to identify the institutional norms that bind scientists to ethical behaviour (Merton, 1973). Prelli explains that the norm of disinterestedness mandates that scientists strive to achieve their own self-interests only by serving the interests of the scientific community, while organized skepticism requires that scientists temporarily suspend judgment in order to scrutinize beliefs critically against empirical and logical criteria of judgment (Merton, 1973, pp. 270-8; Prelli, 1997, p. 88). By these standards, it would be inappropriate for a scientist to be influenced by or use his or her work to forward, for example, a racist ideology.

3 Sir Francis Galton, founder of the eugenics movement, advocated that people of "superior breeding stock" should be sought out and their birth rates increased to make the most of nature-nurture equations. At the same time, the proliferation of "ordinary people" should be reduced or stopped (discussed in Yee, 1995). Notably, Rushton claims that his work belongs in the "London school" tradition, founded by Francis Galton (Rushton, 1995b, p. xvii), and his 1995 book, Race, Evolution, and Behavior, was partially funded by a grant totalling $\$ 656,000$ from the Pioneer Fund (Jennings, Nov. 22, 1994), an organization that supports "research and study into the problems of human race betterment" (The Pioneer Fund Home Page).

4 See Prelli (1997) for a case study of an attempt by Thomas Sebeok to use Mertonian norms to destroy the credibility of primate researcher Francine Patterson.

5 Indeed, the fact that Rushton relies on older published data very heavily has frequently been a target of criticism (cf. Cain \& Vanderwolf, 1990; Cernovsky, 1992, 1995; Luther, 1996; \& Weizmann et al., 1996).

6 Frequent, angry rallies by students (and outside activists) followed the media coverage of Rushton's work in 1989. In the interests of Rushton's personal safety, the University of Western Ontario administration ordered Rushton to lecture by videotape for one term; after he launched formal grievances, he regained the right to teach in person. Several subsequent classes had to be cancelled due to protests, which ceased when the university threatened legal action against the protesters (Rushton, 1994).

7 Rushton appeared as a guest speaker at the American Renaissance 1996 conference. American Renaissance calls itself a "literate, undeceived journal of race, immigration, and the decline of civility" (American Renaissance website). Jared Taylor is the editor of that journal. 


\section{References}

1996 AR conference a huge success. (June 13, 1998). American Renaissance website. <http://www.amren.com/conf96.htm>

Allen, Bem P., \& Adams, J. Q. The concept "race": Let's go back to the beginning. Journal of social behavior and personality, 7 (1), 163-8.

American Renaissance website. (June 13, 1998). <http://www.amren.com/ index.htm>

Cain, Donald P., \& Vanderwolf, C. H. (1990). A critique of Rushton on race, brain size and intelligence. Personality and individual differences, 11 (8), 777-84.

Campbell, Paul Newell. (1975). The personae of scientific discourse. Quarterly journal of speech, 61, 391-405.

Cernovsky, Zack Z. (1992). J. P. Rushton on Negroids and Caucasoids: Statistical concepts and disconfirmatory evidence. The international journal of dynamic assessment and instruction, 2, (2), 55-67.

Cernovsky, Zack Z. (1995). On the similarities of American blacks and whites: A reply to J. P. Rushton. Journal of black studies, 25, (6), 672-9.

Cernovsky, Zack Z. (1996). On J. P. Rushton's methodology in defamation of blacks. In Michael Luther, Ester Cole, and Peter Gamlin (Eds.), Dynamic assessment for instruction: From theory to application. (pp. 25-32). North York, ON: Captus Press.

Fairchild, Halford H. (1991). Scientific racism: The cloak of objectivity. Journal of social issues, 47 (3), 101-15.

Gorey, Kevin M., \& Cryns, Arthur G. (1995). Lack of racial differences in behavior: a quantitative replication of Rushton's (1988) review and an independent meta-analysis. Personality and individual differences, 19 (3), 345-53.

Gross, Alan G. (1991). Rhetoric of science without constraints. Rhetorica, 9, (4), 427-40.

Halloran, S. Michael. (1997). The birth of molecular biology: An essay in the rhetorical criticism of scientific discourse. In Randy Allen Harris (Ed.), Landmark essays on the rhetoric of science. (pp. 39-50). Mahwah, NJ: Hermagoras Press. 
Hyland, K. (1996). Talking to the academy: forms of hedging in scientific research articles. Written communication, 13(2), 251-81.

Jennings, Peter. (Nov. 22, 1994). ABC world news tonight.

Luther, Michael. (1996). The present climate: The bell curve's terrible toll. In Michael Luther, Ester Cole, and Peter Gamlin (Eds.), Dynamic assessment for instruction: from theory to application. (pp. 3-6). North York, ON: Captus Press.

Merton, Robert K. (1973). The normative structure of science. In Robert K. Merton (Aut.) and Norman W. Storer (Ed.), The sociology of science: theoretical and empirical investigations. (pp. 267-78). Chicago: University of Chicago Press.

Miller, Edward M. (1993). Could r selection account for the African personality and life cycle? Personality and individual differences, 15 (6), 665-75.

Pearson, Roger. (1991). Race, intelligence, and bias in academe. Washington, DC: Scott-Townsend Publishers.

Pioneer Fund home page. (July 7, 1998), <www.pioneerfund.org.>

Potter, J. (1996). Representing reality: discourse, rhetoric, and social construction. London: Sage.

Prelli, Lawrence, J. (1997). The rhetorical construction of scientific ethos. In Randy Allen Harris (Ed.), Landmark essays on the rhetoric of science. (pp. 87-104). Mahwah, NJ: Hermagoras Press.

Riley, K. (1991). Passive voice and rhetorical role in scientific writing. Journal of technical writing and communication, 21(3), 239-57.

Rushton, J. Philippe. (1990). Race, brain size, and intelligence: a rejoinder to Cain and Vanderwolf. Personality and individual differences, 11 (8), 785-94.

Rushton, J. Philippe. (1991a). Racial differences: a reply to Zuckerman. American psychologist, 46 (9), 983-4.

Rushton, J. Philippe. (1991b). Race, brain size, and intelligence: Another reply to Cernovsky. Psychological reports, 68, 500-2.

Rushton, J. Philippe. (1994). The equalitarian dogma revisited. Intelligence, 19, 263 80.

Rushton, J. Philippe. (1995a). Asian achievement, brain size, and evolution: comments on A. H. Yee. Educational psychology review, 7 (4), 373-80. 
Rushton, J. Philippe. (1995b). Race, evolution, and behavior. New Brunswick, NJ: Transaction Publishers.

Weizmann, Fredric, Wiener, Neil I., Wiesenthal, David L., \& Ziegler, Michael. Scientific racism in contemporary psychology. In Michael Luther, Ester Cole and Peter Gamlin (Eds.), Dynamic assessment for instruction: from theory to application. (pp. 8-14). North York, ON: Captus Press.

Yee, Albert. H. (1995). Evolution of the nature-nurture controversy: Response to J. Philippe Rushton. Educational psychology review, 7 (4), 381-90.

Zuckerman, M. (1990). Some dubious premises in research and theory on racial differences: scientific, social, and ethical issues. American psychologist, 45, 1297-303.

Zuckerman, M. (1991). Truth and consequences: responses to Rushton and Kendler. American psychologist, 46 (9), 984-6. 